\title{
CONSTRUCTION OF A TAPER TABLE FOR JACK PINE IN SASKATCHEWAN (Pinus Banksiana-Lamb.) ${ }^{1}$

\author{
By C. L. KIRBY ${ }^{2}$
}

C. L. Kirby is a native of Saskatchewan. He was graduated from the University of British Columbia in 1950, where he commenced his studies in forestry in 1946 after being discharged from the Canadian Army. Upon graduation he was employed by the Alaska Pine Co. Ltd., Vancouver, and then by the Federal Forestry Branch, Winnipeg, in 1951. Finally he returned to his home town, Prince Albert, in October 1953, to be employed by the Department of Natural Resources, Saskatchewan.

\section{ABSTRACT}

A taper table has been developed for jack pine of average form in Saskatchewan. The table is strongly weighted for diameters up to 12 inches and heights up to 70 feet. Beyond these limits the reliability of the table is limited because of the lack of data.

The average taper of jack pine in Saskatchewan has proven to be quite similar to that of the Lake States. Therefore, much of the volume table work done in the Lake States should be applicable in Saskatchewan.

From the taper table developed for Saskatchewan, volume tables may be constructed on the basis of any desired standard: board foot or cubic foot; any specified top diameter limit; total height or merchantable height. Also, it is possible to determine how many bolts of different diameters, poles or ties can be utilized from each height-diameter class. The table represents average conditions where the average form class of the stand is approximately 65. No allowances for defect have been made.

The purpose of this study on taper was twofold:-

1. To study taper as a variable in jack pine of Saskatchewan.

2. To prepare a taper table for the jack pine of average form in Saskatchewan.

Taper as a Variable in Jack Pine of Saskatchewan

Data that can be used for the construction of taper tables has been collected by the Forest Inventory Division during the past few years over a wide range of jack pine areas in Saskatchewan. The areas represented are as follows: Cumberland Lake, Flin Flon, Meadow Lake, Northern Area (between the 55th and 56th parallels), Hudson Bay, Candle Lake, Fort a la Corne, Bittern Lake, Flotten Lake, White Fox, Keeley Lake, and the northern portion of the Prince Albert area "Nito". Nine hundred and thirty-eight trees were measured, with the diameters inside and outside bark measured at 8.1-foot intervals from a 1.0 -foot stump to a 3.0 -inch top and at 4.5 -feet (breast height) above ground. The number of trees by form class and areas is presented in Table I.

\footnotetext{
Submitted for publication January 26, 1955.

- Forestry Branch, Department of Natural Resources, Prince Albert.
} 
TABLE I

Distribution of Data by Area and Form Class

\begin{tabular}{|c|c|c|c|c|c|c|c|c|c|c|c|}
\hline \multirow[b]{2}{*}{ Area } & \multicolumn{4}{|r|}{ Form } & \multicolumn{3}{|c|}{ Class } & \multirow[b]{2}{*}{80} & \multirow{2}{*}{\multicolumn{2}{|c|}{ 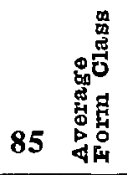 }} & \multirow{2}{*}{ 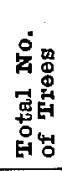 } \\
\hline & 45 & $\mathbf{5 0}$ & 55 & 60 & 65 & $\mathbf{7 0}$ & 75 & & & & \\
\hline Torch, Dore, Nito & 2 & 7 & 15 & 32 & 43 & 41 & 15 & 10 & --- & 65.3 & 165 \\
\hline Candle Lake, Fort a la Corne & 4 & --- & 38 & 43 & 88 & 69 & 15 & 5 & 1 & 64.7 & 263 \\
\hline Bittern Lake & --- & 2 & 12 & 29 & 37 & 36 & 19 & 3 & 1 & 66.0 & 139 \\
\hline Meadow Lake (Inventory) & 4 & 8 & 11 & 22 & 39 & 36 & 14 & 5 & 2 & 65.1 & 141 \\
\hline Meadow Lake (Thinning) & 3 & 5 & 17 & 23 & 10 & 7 & 2 & 2 & 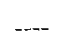 & 60.1 & 69 \\
\hline Northern Reconnaissance & 1 & 1 & --- & 2 & 7 & 6 & 2 & 1 & --- & 66.0 & 20 \\
\hline Cumberland Lake, Flin Flon & 2 & 3 & 9 & 11 & 12 & 11 & 2 & 2 & --- & 62.6 & 50 \\
\hline Hudson Bay (Dominion & & & & & & & & & & & \\
\hline Measurements) & 1 & 1 & 3 & 8 & 27 & 24 & 9 & 2 & --- & 66.8 & 75 \\
\hline $\begin{array}{l}\text { Flotten Lake, Keeley Lake, } \\
\text { White Fox (Growth Plots) }\end{array}$ & 1 & & $\ldots$ & 8 & 5 & -..- & --- & --- & --- & 60.1 & 14 \\
\hline TOTALS & 18 & 27 & 105 & 178 & 268 & 230 & 78 & 30 & 4 & & 938 \\
\hline
\end{tabular}

Average Form Class - 64.7

Standard Deviation - 7.3

The average form class for all areas and diameter classes grouped together is approximately 65. The Meadow Lake area, where trees were measured from a thinning operation, shows a lower-than-average form class. This is due to the fact that the trees measured were in the lower crown classes and of poor form, and were not representative of the stand. In the growth plots where only fourteen trees were measured, a lower-than-average form class was shown. This may be because an insufficiency of sampling has not shown the true average form class of the stand. In most cases the average form class for an individual area is within two form-class units of the average for all the areas examined. Therefore, the use of average taper curves should be applicable over a wide range of jack pine areas.

The absolute form quotient is obtained by dividing the diameter inside bark at breast height into the diameter inside bark at half the height above breast height. A form class is a group of form quotients expressed as a percentage, usually to the nearest five per cent. The form quotient has proved to be a good measure of taper.

A normal distribution of form classes is approached when all the areas given in Table I are grouped together in one-inch diameter classes. Rejecting all measurements that deviate by more than two standard deviations from the mean form class of 65 gives the most probable range as 50 to 80 form class units for jack pine in Saskatchewan.

In order that the construction of the taper table would represent trees of average form, it was decided to take only trees within one standard deviation 
of the mean form class. This took in all trees in form classes of 60 to 70 , or 72 per cent of the measurements (676 trees). These trees were considered to be the most representative of the areas measured. The average form class of trees used in the taper table construction was 65.4. The average form class will not be approached in areas where extremes of over-stocking and under-stocking are encountered.

In correlating form class and diameter there is a trend for form to decrease with increases in diameter. This is shown in Table II and Figure I.

TABLE II

Form Class and Diameter Breast Height Relationship

\begin{tabular}{|c|c|c|c|c|c|c|c|c|c|c|c|}
\hline 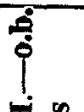 & & & & & $\mathrm{rm}$ & & & & & 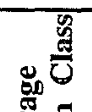 & $\dot{z}$ \\
\hline 0 & 45 & 50 & 55 & 60 & 65 & 70 & 75 & 80 & 85 & $\sum^{2}$ & है \\
\hline 3 & 1 & ...- & w-. & $\ldots$ & 1 & $\ldots$ & 1 & 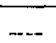 & $\ldots$ & 61.0 & 3 \\
\hline 4 & 1 & 1 & 9 & 10 & 25 & 17 & 16 & 10 & 1 & 67.7 & 90 \\
\hline 5 & 1 & 3 & 10 & 23 & 29 & 19 & 6 & 5 & 1 & 64.9 & 97 \\
\hline 6 & 3 & 5 & 12 & 25 & 32 & 26 & 5 & 3 & 1 & 63.8 & 112 \\
\hline 7 & 1 & 2 & 5 & 16 & 24 & 37 & 15 & 2 & 1 & 66.7 & 103 \\
\hline 8 & 4 & 2 & 12 & 10 & 28 & 25 & 5 & 1 & $\ldots$ & 63.6 & 87 \\
\hline 9 & $\ldots$ & 3 & 6 & 25 & 21 & 30 & 13 & 2 & $\ldots$ & 65.6 & 100 \\
\hline 10 & ---. & 2 & 18 & 21 & 43 & 43 & 9 & 4 & $\ldots$ & 65.2 & 140 \\
\hline 11 & 3 & 4 & 17 & 23 & 40 & 24 & 6 & 2 & $\ldots$ & 63.2 & 119 \\
\hline 12 & 2 & 3 & 9 & 17 & 11 & 7 & 2 & $\ldots$ & $\ldots$ & 61.2 & 51 \\
\hline 13 & 1 & 1 & 2 & 2 & 12 & 1 & $\ldots$ & 1 & $\ldots$ & 62.6 & 20 \\
\hline 14 & 1 & ב-ב & 5 & 3 & --- & 1 & -..- & $\ldots$ & $\ldots$ & 57.0 & 10 \\
\hline 15 & .... & .... & $\ldots$ & 2 & 1 & $\ldots$ & $\ldots$ & $\ldots$ & $\ldots$ & 61.7 & 3 \\
\hline 16 & $\ldots$ & -.-- & - & 1 & 1 & $\ldots$ & -.-- & $\ldots$ & $\ldots$ & 62.5 & 2 \\
\hline 17 & $\ldots$ & 1 & $\ldots$ & -..- & .... & 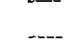 & $\ldots$ & $\ldots$ & $\ldots$ & 50.0 & 1 \\
\hline Total & 318 & 27 & 105 & 178 & 268 & 230 & 78 & 30 & 4 & & 938 \\
\hline
\end{tabular}

FIGURE I

Distribution of Form Classes by Diameter Classes

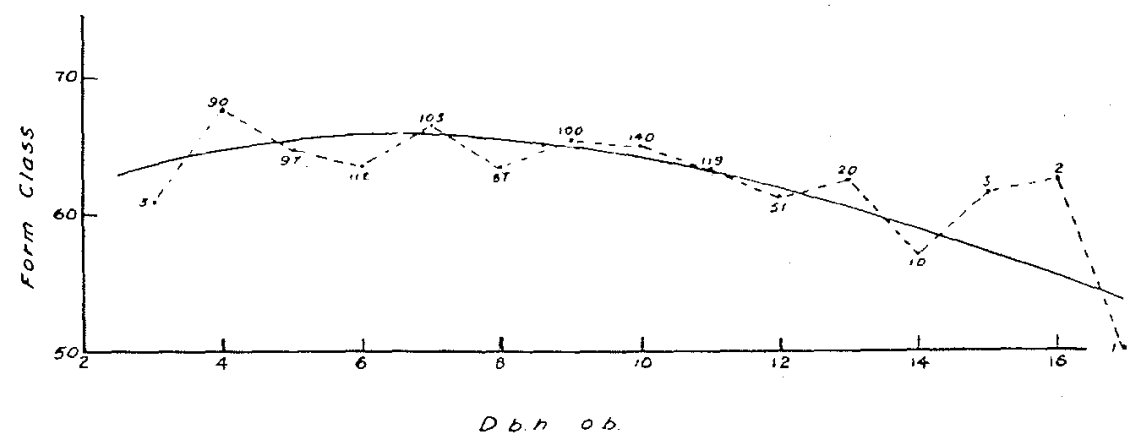


In future, should it be desired to have more accurate considerations of form, form class may be correlated with density or some other growth factors. In this study, the variation of form class could not be correlated with density or age, because measurements of these variables were not available. In Europe the average form of the stand is correlated with the density of the stand.

\section{Construction of TAPer Tables}

W. B. Barrows' method, as outlined in Chapman's Forest Mensuration, was used for the construction of the taper table. This method simply harmonized the average values of the basic data. The basic data used were measurements of trees with a form class of 60,65 and 70 .

The data were grouped by one-inch diameter classes and ten-foot height classes. The average diameter inside bark for the measurements above ground was determined for each diameter-height group as follows:

TABLE III

Four-Inch DBH. Group and Twenty-Foot Height Class

\begin{tabular}{|c|c|c|c|c|c|c|c|c|}
\hline & & $\overline{\text { Dir }}$ & ters & ide Ba & at $\mathrm{H}$ & ight $A$ & ove & \\
\hline & Measured & & & Ground & feet) & & & Total \\
\hline & DBH.-o.b. & 1.0 & 4.5 & 9.1 & 17.2 & 25.3 & 33.4 & Height \\
\hline & 3.6 & 4.2 & 3.3 & 3.1 & --- & -.. & ---- & $\overline{24.0}$ \\
\hline & 4.0 & 4.1 & 3.8 & 3.0 & - & -_ & --.. & 22.0 \\
\hline & 3.6 & 3.3 & 3.4 & 2.5 & - & $\ldots$ & - & 18.5 \\
\hline & 4.4 & 5.1 & 4.0 & 3.3 & $\ldots$ & --- & $\ldots$ & 22.0 \\
\hline Total & 15.6 & 16.7 & 14.5 & 11.9 & - & - & - & 86.5 \\
\hline Average & 3.9 & 4.2 & 3.6 & 3.0 & $\ldots$ & - & $\ldots$ & 21.6 \\
\hline
\end{tabular}

The harmonizing of these averages of each diameter-height group was accomplished by two curvings:

\section{First Curving}

The purpose of the first curving was to smooth out the average values in each height class. This was done on the basis that the upper diameters would diminish in direct proportion with diminishing diameter breast-height outside bark. A straight-line relationship is suggested by Barrows. This linear relationship was calculated for each point of measurement up the stem in each height class by the method of least squares as described by Meyer for regression lines originating from the origin. This curving is demonstrated by the following curves constructed for the twenty-foot height class.

\section{Second Curving}

The next curving was to harmonize the upper diameters measured at the same height above ground on trees of different height classes, but of the same diameter class. The values used in this curving were obtained from the first set of curves drawn. The independent variable consisted now of all the height classes within a diameter class. This harmonized values for the same diameter class, but of different height classes. Free hand curves were used to harmonize the values obtained from the first curving. This curving in some cases left much to personal judgment. For example, for the measurements taken at breast 
FORESTRY CHRONICLE

Example of the first curving for the 20-foot height class
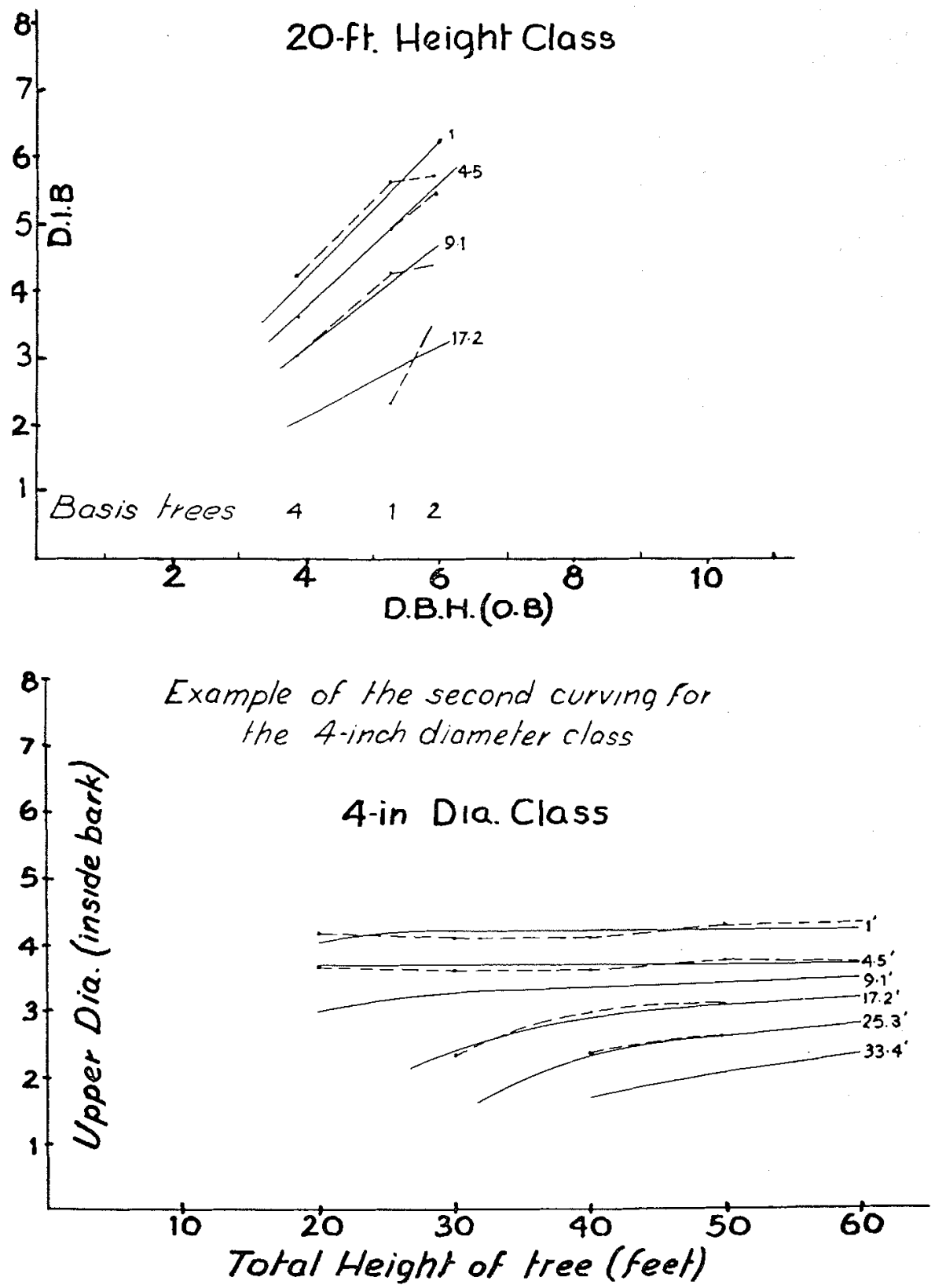
height (4.5 feet) with increasing total height and the same diameter breast height outside bark, should the diameter inside bark increase, decrease, or remain constant? Any variation would be due to thickness of bark. It would seem logical that the higher trees of the same diameter class would be older and have the thicker bark. Therefore, the diameter inside bark should decrease. Gevorkiantz found the diameter inside bark to increase. In this study there was in some cases a slight trend for diameter inside bark to increase, but in general the diameter inside bark at breast height remained constant for all height classes.

The origin of each curve was fixed on the total height scale. That is, measurements at 41.5 feet had to have a diameter inside bark of zero when the total height of the tree was 41.5 feet. This curving is demonstrated by the following curve constructed for the four-inch diameter class. Further cross curving as outlined by Barrows was not found necessary, because values obtained in the second curving when plotted as d.i.b. over height gave smooth taper curves of concentric form.

A taper table has been derived from the second set of curves and is presented in Table IV.

TABLE IV

TAPer TABle For JACK Pine

(Pinus Banksiana)

\begin{tabular}{|c|c|c|c|c|c|c|c|c|c|c|c|c|c|}
\hline 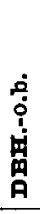 & 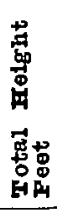 & $\begin{array}{l}\text { Di } \\
1\end{array}$ & $\begin{array}{l}\text { eter } \\
4.5\end{array}$ & $\begin{array}{r}\text { Inside } \\
9.1\end{array}$ & $\begin{array}{c}\text { Bark at } \\
17.2\end{array}$ & $\begin{array}{l}\text { Hoig. } \\
25.3\end{array}$ & $\begin{array}{r}\text { ht } A b c \\
33.4\end{array}$ & $\begin{array}{r}41.5 \\
41.5\end{array}$ & $\begin{array}{l}\text { Ground- } \\
5 \quad 49.6\end{array}$ & $\begin{array}{c}\text {-(In } \\
57.7\end{array}$ & $\begin{array}{r}\text { Peet) } \\
65.8\end{array}$ & 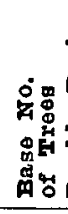 & 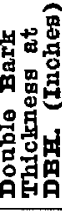 \\
\hline \multirow[t]{4}{*}{4} & 20 & 4.1 & 3.7 & 3.0 & ב.- & --_- & --.- & ---- & -..- & ---- & ---- & 4 & 0.3 \\
\hline & 30 & 4.2 & 3.7 & 3.2 & 2.4 & ... & .... & ---. & .... & -.- & --.- & 22 & \\
\hline & 40 & 4.2 & 3.7 & 3.3 & 2.9 & 2.3 & --.- & --. & --.- & ---- & --- & 17 & \\
\hline & 50 & 4.2 & 3.7 & 3.4 & 3.1 & 2.6 & -..- & - & $\ldots$ & -.- & -..- & 6 & \\
\hline \multirow[t]{5}{*}{5} & 20 & 5.0 & 4.6 & 3.9 & 1.6 & -... & -... & $\ldots$ & --- & -.- & ---- & 1 & 0.4 \\
\hline & 30 & 5.1 & 4.6 & 4.0 & 3.1 & ---- & -..- & $\ldots$ & -..- & - & -..- & 13 & \\
\hline & 40 & 5.2 & 4.6 & 4.1 & 3.5 & 2.9 & - & $\ldots$ & - &.-- & 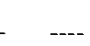 & 17 & \\
\hline & 50 & 5.4 & 4.6 & 4.3 & 3.8 & 3.3 & 2.6 & $-\ldots$ & -.-- & -.- & -ב-_- & 29 & \\
\hline & 60 & 5.5 & 4.6 & 4.4 & 4.0 & 3.6 & 3.1 & $\ldots$ & --- & ---- & $-\cdots$ & 9 & \\
\hline \multirow[t]{6}{*}{6} & 20 & 6.1 & 5.5 & 4.6 & 1.5 & ---- & ---- & - & ---- & ---- & ---- & 2 & 0.5 \\
\hline & 30 & 6.1 & 5.5 & 4.9 & 3.5 & ---- & -... & -- & .... & - & $\ldots$ & 5 & \\
\hline & 40 & 6.1 & 5.5 & 5.1 & 4.3 & 3.5 & $\ldots$ & - & - & - & - & 19 & \\
\hline & 50 & 6.2 & 5.5 & 5.2 & 4.6 & 4.0 & 3.2 & - & $\ldots$ & -- & $-\ldots$ & 27 & \\
\hline & 60 & 6.3 & 5.5 & 5.3 & 4.7 & 4.2 & 3.5 & 2.9 & ---- & $\ldots$ & --.- & 25 & \\
\hline & 70 & 6.6 & 5.5 & 5.3 & 4.8 & 4.4 & 3.9 & 3.4 & $\ldots$ & $\ldots$ & $-\ldots$ & 2 & \\
\hline
\end{tabular}


TABLE IV (continued)

\begin{tabular}{|c|c|c|c|c|c|c|c|c|c|c|c|c|c|}
\hline 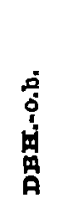 & 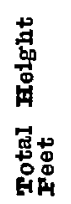 & $\begin{array}{l}\mathbf{D} \mathbf{1} \\
\mathbf{1}\end{array}$ & $\begin{array}{r}\text { meter } \\
4.5\end{array}$ & $\begin{array}{r}\text { Inside } \\
9.1\end{array}$ & $\begin{array}{c}\text { Barix at } \\
17.2\end{array}$ & $\begin{array}{l}\text { Helgh } \\
25.3\end{array}$ & $\begin{array}{r}\text { ht Abo } \\
33.4\end{array}$ & $\begin{array}{c}\text { DVe GI } \\
41.5\end{array}$ & $\begin{array}{r}\text { round- } \\
49.6\end{array}$ & $\begin{array}{r}-(\mathrm{In} \\
57.7\end{array}$ & $\begin{array}{r}\text { Yeet) } \\
65.8\end{array}$ & & \\
\hline 7 & $\begin{array}{l}30 \\
40 \\
50 \\
60 \\
70\end{array}$ & $\begin{array}{l}7 . \\
7 . \\
7 . \\
7 .\end{array}$ & $\begin{array}{l}6 \\
6 \\
6\end{array}$ & & & & $\begin{array}{l}2.2 \\
3.6 \\
4.2 \\
4.6\end{array}$ & $\begin{array}{l}- \\
-2.1 \\
3.3 \\
4.0\end{array}$ & - & $\begin{array}{l}- \\
- \\
- \\
-\end{array}$ & - & $\begin{array}{r}2 \\
3 \\
22 \\
35 \\
8\end{array}$ & 0.5 \\
\hline 8 & $\begin{array}{l}30 \\
40 \\
50 \\
60 \\
70\end{array}$ & $\begin{array}{l}8 . \\
8 . \\
8 . \\
8 . \\
8 .\end{array}$ & 7 & & & & $\begin{array}{l}2.8 \\
4.1 \\
4.8 \\
5.2\end{array}$ & $\begin{array}{l}- \\
\overline{3.0} \\
3.9 \\
4.6\end{array}$ & $\begin{array}{l}\cdots \\
\cdots \\
2.8 \\
3.8\end{array}$ & $\overline{-}$ & $\begin{array}{l}- \\
- \\
\cdots \\
\cdots\end{array}$ & $\begin{array}{r}3 \\
2 \\
16 \\
23 \\
23\end{array}$ & 0.6 \\
\hline 9 & $\begin{array}{l}40 \\
50 \\
60 \\
70 \\
80\end{array}$ & $\begin{array}{l}9 . \\
9 \\
9 \\
9 \\
9\end{array}$ & 8 & & & & $\begin{array}{l}3.5 \\
4.6 \\
5.4 \\
6.0 \\
6.3\end{array}$ & $\begin{array}{l}-\overline{3.4} \\
4.2 \\
5.1 \\
5.7\end{array}$ & $\begin{array}{l}- \\
3.2 \\
4.2 \\
5.1\end{array}$ & $\begin{array}{c}- \\
\overline{-} \\
3.3 \\
4.4\end{array}$ & $\begin{array}{c}- \\
\cdots \\
\cdots \\
- \\
3.3\end{array}$ & $\begin{array}{r}2 \\
11 \\
35 \\
24 \\
5\end{array}$ & .6 \\
\hline 10 & $\begin{array}{l}50 \\
60 \\
70 \\
80\end{array}$ & & & & & & $\begin{array}{l}6.0 \\
6.6 \\
7.0\end{array}$ & $\begin{array}{l}3.7 \\
4.8 \\
5.7 \\
6.3\end{array}$ & $\begin{array}{l} \\
3.6 \\
4.6 \\
5.6\end{array}$ & $\begin{array}{l}- \\
- \\
3.7 \\
4.9\end{array}$ & ב.7 & $\begin{array}{l}11 \\
52 \\
32 \\
15\end{array}$ & 0.7 \\
\hline 11 & $\begin{array}{l}50 \\
60 \\
70 \\
80\end{array}$ & $\begin{array}{l}11.6 \\
11.7 \\
11.8 \\
11.9\end{array}$ & 10 & & & & $\begin{array}{l}5.7 \\
6.6 \\
7.2 \\
7.7\end{array}$ & $\begin{array}{l}3.7 \\
5.2 \\
6.2 \\
7.0\end{array}$ & $\begin{array}{l}3.8 \\
5.1 \\
6.2\end{array}$ & $\begin{array}{l}- \\
4.0 \\
5.3\end{array}$ & $\overline{\overline{-}}$ & $\begin{array}{r}10 \\
48 \\
22 \\
8\end{array}$ & 0.7 \\
\hline 12 & $\begin{array}{l}50 \\
60 \\
70\end{array}$ & & & & & & $\begin{array}{l}6.2 \\
7.2 \\
7.9\end{array}$ & $\begin{array}{l}4.4 \\
5.6 \\
6.6\end{array}$ & $\begin{array}{l}\overline{4.1} \\
5.1\end{array}$ & $\overline{4.0}$ & - & $\begin{array}{r}6 \\
24 \\
6\end{array}$ & 0 \\
\hline 13 & $\begin{array}{l}50 \\
60 \\
70\end{array}$ & $\begin{array}{l}13.8 \\
13.9 \\
14.0\end{array}$ & 12.1 & & & & & $\begin{array}{l}4.9 \\
6.0 \\
7.1\end{array}$ & $\begin{array}{l}3.2 \\
4.4 \\
5.6\end{array}$ & 4.2 & - & $\begin{array}{l}2 \\
9 \\
3\end{array}$ & 0.9 \\
\hline 14 & $\begin{array}{l}60 \\
70\end{array}$ & $\begin{array}{l}14.8 \\
14.8\end{array}$ & & & & & & $\begin{array}{l}6.2 \\
7.4\end{array}$ & $\begin{array}{l}4.6 \\
5.6\end{array}$ & 4.2 & --.- & $\begin{array}{l}1 \\
3\end{array}$ & 1.0 \\
\hline 15 & $\begin{array}{l}60 \\
70\end{array}$ & $\begin{array}{l}16.0 \\
16.0\end{array}$ & & & & & $\begin{array}{l}7.9 \\
8.8\end{array}$ & $\begin{array}{l}6.4 \\
7.6\end{array}$ & $\begin{array}{l}4.6 \\
5.8\end{array}$ & 4.2 & $\ldots$ & $\begin{array}{l}3 \\
1\end{array}$ & 1.0 \\
\hline 16 & $\begin{array}{l}60 \\
70\end{array}$ & & & & & & & $\begin{array}{l}6.5 \\
7.7\end{array}$ & $\begin{array}{l}4.8 \\
6.9\end{array}$ & $\overline{4.3}$ & $\ldots$ & 1 & 1.1 \\
\hline
\end{tabular}




\section{Comparison of Taper Curve Volumes with a Dominion Form Class Volume Table}

The average taper curves plotted on tree measurement sheets were planimetered from a one-foot stump to a three-inch top and the cubic foot volume calculated. These volumes were compared with the Dominion Forest Service's Form Class Volume Table, second edition Table No. 30 (cubic foot volume for jack pine of form-class 65, from a one-foot stump to a three-inch top). The volumes from the average taper curves and Table No. 30 were plotted on double logarithmic paper and compared by height classes. Volumes over diameter plot as nearly a straight line for each height class. A comparison by height classes is as follows:-

\section{Height Class \\ Volume Comparison}

80

70

60

The average taper curve volumes are four per cent higher. The average taper curve volumes are identical with the Dominion Table.

The average taper curves are from 0 to 8 per cent higher for diameters under 7 inches and from 0 to 8 per cent lower for diameters over 7 inches.

The average taper curves are from 0 to 8 per cent higher for diameters under 8 inches and from 0 to 8 per cent lower for diameters over 8 inches.

The average taper curves are approximately 3 per cent higher.

The average taper curve volumes are approximately 14 per cent higher.

Assuming that the average taper curves represent trees of average volume, it is demonstrated that the use of a single form-class volume table is not applicable for all diameters and heights. The largest divergence is in the thirtyfoot height class. It appears that these deviations would have been smaller if the volumes from the Dominion table had been interpolated for form class for each diameter class. See Figure I for the variation of form class with diameter.

\section{Comparison of TAPer Tables for Jack Pine of THE Lake States and Saskatchewan}

A similar table had been developed for jack pine in the Lake States by S. R. Gevorkiantz. A comparison of the two tables showed the taper curves to be quite similar for trees up to twelve inches in diameter. From the measurements available, the Saskatchewan jack pine has the better form in general for diameters over twelve inches. This may be due to:

1. Different methods used in constructing the tables.

2. Insufficient data in diameter classes over twelve inches, and the measurements available having better-than-average form.

3. Thicker bark on the jack pine of the Lake States on diameters over twelve inches.

Because of the similarity of taper in the two regions for diameters up to 
twelve inches, and the large preponderance of trees whose diameter is twelve inches and under in jack pine stands of Saskatchewan, much of the work on volume tables for jack pine in the Lake States may be used in Saskatchewan.

\section{REFERENCES}

1. BEHRE, E. C. Form Class Taper Curves and Volume Tables and Their Applicarion, Journal of Agricultural Research, Volume 30, No. 8, Washington, D.C., 1927.

2. CHAPMAN, H. H. Forest Mensuration, John Wiley \& Sons, New York, 1921.

3. EYRE, F. H. AND RUSSEL K. LEBARRON, Management of Jack Pine Stands in the Lake States, Technical Bulletin No. 863, United States Deparement of Agriculture, Washington, D.C.

4. Form Class Volume Tables, Second Edition, Department of Mines and Resources, Ottawa, 1948.

5. GEVORKIANTZ, S. R. Jack Pine Taper Table, Technical Note No. 155, Lake States Experimental Station, University Farm, St. Paul, Minnesota, 1939.

6. MEYER, H. A. Methods of Forest Growth Determination, The Pennsylvania State College, School of Agriculture, Agricultural Experiment Station, State College, Pennsylvania, Bulletin 435,1942 .

7. WRIGHT, W. G. Taper As a Factor In The Measurement of Standing Timber, Canada Department of Mines and Resources, Dominion Forest Service, Bulletin 79, 1927. 